LIAMES, Campinas, SP, v. 20, 1-21, e020001, 2020

\title{
Adverbial clauses in Veracruz Huasteca Nahuatl from a functional-typological approach
}

\author{
Jesús Francisco Olguín-Martínez \\ Universidad de California en Santa Barbara, E.U. \\ https://orcid.org/0000-0002-4555-4213 \\ Zarina Estrada-Fernández \\ Universidad de Sonora, México \\ https://orcid.org/0000-0001-7249-2452
}

\begin{abstract}
This paper analyses adverbial clauses in Veracruz Huasteca Nahuatl (vHN), a Uto-Aztecan language spoken in Mexico. We argue that the formal properties of adverbial clauses in vHN are motivated by general functional principles, particularly, their semantic values. We address seven semantic relations: temporal precedence, temporal subsequence, temporal simultaneity, cause/reason, purpose, result, and spatial relations. We support the analysis not only with evidence from VHN, but also from other languages of the world where two morphosyntactic devices are important: adverbial conjunctions and TAM morphology. Our main claim is that the different semantic relations encoded within adverbial clauses take on specific formal mechanisms to express those particular communicative situations.
\end{abstract}

KEYWORDS: Adverbial clauses; Semantic relation; Nahuatl.

RESUMEN: Este trabajo analiza las cláusulas adverbiales en náhuatl de la Huasteca veracruzana (NHV), lengua yuto-azteca hablada en México. Argumentamos que las propiedades formales de las cláusulas adverbiales en NHV están motivadas por principios funcionales de carácter general, particularmente, sus valores semánticos. Nos concentramos en siete relaciones semánticas: precedencia temporal, subsecuencia temporal, simultaneidad temporal, causa/razón, propósito, resultado y relaciones espaciales. Sostenemos nuestro análisis no solo con evidencias de NHV, sino también de otras lenguas del mundo donde dos propiedades morfosintácticas son importantes: las conjunciones adverbiales y la morfología TAM. Nuestra principal propuesta es que las diferentes relaciones semánticas codificadas en las cláusulas adverbiales se apoyan en ciertos mecanismos formales para expresar situaciones comunicativas particulares.

PALABRas Clave: Cláusulas adverbiales; Relaciones semánticas; Náhuatl.

\section{Introduction ${ }^{1}$}

Adverbial clauses have been analyzed by different authors, from different perspectives (e.g. Kortmann 1997, on the function and form of adverbial conjunctions in European

${ }^{1}$ This work benefitted immeasurably from discussions with Bernard Comrie, Susan Steele, and Michael Galant. Any errors remain entirely our responsibility.

DOI: http://dx.doi.org/10.20396/liames.v20i0.8657281 
languages, Dixon 2009, on the semantics of adverbial clauses in typological perspective, and Cristofaro 2003, on the downgrading hierarchy of adverbial clauses). However, few functional cross-linguistic studies have explored how different formal devices are predetermined by adverbial clauses (but see Hetterle 2015: 74; Cristofaro 2003: 111). For instance, Schmidtke-Bode (2009: 43) explains that since purposes are future-oriented this semantic relation tends, cross-linguistically, to take future, non-past, or imperfective marking.

In this paper we aim to contribute to this theoretical discussion by exploring the functional domain of adverbial clauses in Veracruz Huasteca Nahuatl (vHN), a UtoAztecan language spoken in Mexico. The aims of this paper are twofold: (i) to uncover the general functional principles and motivations that shape and constrain different formal mechanisms, such as tempo-aspectual suffixes and phrasal adverbs, in different semantic relations and (ii) to situate VHN adverbial clauses within the phenomenon of clause linkage cross-linguistically. The theoretical background of the present study is based on the framework developed within the functional-typological approach which mainly focuses on the role of functional factors at all levels of grammatical analysis (Comrie 1981; Givón 2001).

The structure of this paper is as follows: In Section 2, we provide some basic grammatical information for VHN. Section 3 explains some theoretical remarks of adverbial clauses. In Section 4, we explore adverbial clauses in vHN. Finally, the paper concludes in Section 5 with some final comments. ${ }^{2}$

\section{Typological profile of $\mathrm{VNH}$}

According to Campbell (1997) and Dakin (2004), Nahuatl is a Southern Uto-Aztecan language that belongs to the Corachol-Aztecan branch. The language is polysynthetic with agglutinative tendency since words are composed of several morphemes. A simple clause in this language may only consist of a verbal word encoding not only the participants, but also voice information, such as valence change mechanisms, TAM markers, illocutionary markers, and negative markers, among others. The grammatical relations of the arguments in any clause of VHN are marked by a set of pronominal indexes, which are either bound to a nominal element if they refer to a possessor, or bound to a verb if they refer to the subject or object argument of a verb, see Table 1. The language also has a set of independent pronouns, as in Table 2.

${ }^{2}$ The data we use in this paper comes largely from a period of fieldwork in Teposteco, Chicontepec, Veracruz in 2016. We warmly thank the three Nahuatl speakers who agreed to share with us some of their language knowledge. 
Table 1. Bound pronouns in VHN (Peregrina 2015)

\begin{tabular}{|c|c|c|c|c|c|c|c|}
\hline Number & Person & Subject & Object & $\begin{array}{l}\text { Reflexive } \\
\text { Reciprocal } \\
\text { Medial }\end{array}$ & $\begin{array}{l}\text { Human } \\
\text { Unspecified } \\
\text { Object }\end{array}$ & $\begin{array}{l}\text { Non-human } \\
\text { Unspecified } \\
\text { Object }\end{array}$ & Possessive \\
\hline \multirow{3}{*}{ Singular } & $1^{\text {st }}$ & ni- & nech- & \multirow{6}{*}{ mo- } & \multirow{6}{*}{ te- } & \multirow{6}{*}{ tla- } & no- \\
\hline & $2^{\text {nd }}$ & ti- & mits- & & & & mo- \\
\hline & $3^{\text {rd }}$ & & ki- & & & & i- \\
\hline \multirow{3}{*}{ Plural } & $1^{\mathrm{st}}$ & ti- & tech- & & & & to- \\
\hline & $2^{\text {nd }}$ & in- & amech- & & & & amo- \\
\hline & $3^{\text {rd }}$ & & kin- & & & & in- \\
\hline
\end{tabular}

Optional free pronouns are also available in vHN; the list of them are provided in Table 2.

Table 2. Free pronouns in VHN (Peregrina 2015)

\begin{tabular}{|c|c|c|}
\hline Number & Person & Single form \\
\hline \multirow{3}{*}{ Singular } & $1^{\text {st }}$ & na \\
\cline { 2 - 3 } & $2^{\text {nd }}$ & ta \\
\cline { 2 - 3 } & $3^{\text {rd }}$ & ya \\
\hline \multirow{3}{*}{ Plural } & $1^{\text {st }}$ & tohuanti \\
\cline { 2 - 3 } & $2^{\text {nd }}$ & anohuanti \\
\cline { 2 - 3 } & $3^{\text {rd }}$ & inohuanti \\
\hline
\end{tabular}

VHN is a language with no case marking on lexical arguments, i.e. noun phrases, although bound pronouns affixed to a verbal root play a crucial role in determining the function of the participants where subject and object indexes are on the verb. Thus, according to the behavior of these elements, VHN is a nominative-accusative language since the single argument of an intransitive construction, the subject (s), and the agent argument (A) of a transitive construction are marked in the same way $(\mathrm{S}=\mathrm{A})$, while the patient argument $(\mathrm{P})$ of the transitive construction is marked differently $(\mathrm{P} \neq \mathrm{A})$. Observe that in (1), the argument $\mathrm{s}$ in the intransitive clause, the noun phrase nosihua 'my wife', agrees with a zero marking of a third person singular subject at the verbal root, kuatsah 'to scream'. On the other hand, in the example in (2), the agent participant A, nopa toahui 'the woman', of the transitive construction agrees with the zero marking of a third person singular subject of the verbal root kuah 'to eat'. Meanwhile, the P participant, tamali 'tamales', agrees with the third person plural object pronominal index kin-. 
(1) no-sihua ø-kuatsah-skia.

1sG.POSS-wife 3sG.SBJ-scream-COND ${ }^{3}$

'My wife would scream.'

(2) nopa toahui ø-kin-kuah-ki

DET woman 3sG.SBJ-3PL.OBJ-eat-PFV

'The woman ate tamales.' tama-li.

tamales-ABS

An important morphological property of this language is that it distinguishes between possessive vs. non-possessive nouns by a set of suffixes. An example of the absolutive suffix is observed in (2), where the lexical noun tama-li 'tamale' is marked with the absolutive suffix -li. The use of this label must not be confused with the absolutive case marker that is observed in ergative-absolutive languages. The origin of the label absolutive in Nahuatl has its roots in the colonial grammars written by Jesuits priests, among them Carochi (1645). In (2) the noun tamali 'tamales-ABs' bears the absolutive suffix -li, which alternates with $-t l i$, $-t l$, and $-t$.

The last typological feature that we consider is that VHN is a head-marking language, since the predicate marks the obligatory encoding of the subject and object. In the example in (3), the single argument is marked on the verbal root yohui 'to go'. In the same manner, in (4) the two arguments are marked on the verbal root kuah 'to eat'. This supports the idea that VHN is a head-marking language.

(3) ni-yohui-yaya.

1sG.SBJ-go-IPFV

'I was leaving.'

(4) ni-kin-kuah-ki

1sG.SBJ-3PL.OBJ-eat-PFV tamales-ABS ${ }^{5}$

'I ate tamales.'

${ }^{3}$ The glosses follow the Leipzig Glossing Rules (http://www.eva.mpg.de/lingua/resources/glossing-rules. php). Abbreviations: 1 first person, 2 second person, 3 third person, ABS absolutive, AFF affirmative, AOR aorist, APPL applicative, ART article, CAUS causative, DIM diminutive, DIR directional, EMPH emphatic, FUT future, GEN genitive, GNL general, INCH inchoative, IPFV imperfective, LIG ligature, LOC locative, NEG negation, OBJ object, PFV perfective, PL plural, POSS possessive, POSTR posterior marker, PREP preposition, PRES present, PST past, PURP purpose, RDP reduplication, REFL reflexive, SBJ subject, SG singular, SREL superlative case, SRESS superessive case, SUB subordinator, TOP topic marker, UNSPEC unspecified.

${ }^{4}$ See Whorf(1937), Andrews (1975), Canger (1997), and Sullivan (1988) for more information concerning the absolutive suffix in Nahuatl. Launey (2011) prefers the label 'absolute'.

${ }^{5}$ Traditionally, Nahuatl has been described as distinguishing between the absolutive form of a noun and the possessed form. The absolutive suffix $-t l$, $-t$ or $-l$ according to the different variety of Náhuatl -in Launey's terms absolute marker-, appears within Nahuatl nouns to indicate that the entity referred by the noun is not possessed. 


\section{Adverbial clauses: Some brief theoretical remarks}

The most relevant step when analyzing the functional domain of any linguistic phenomenon is to establish the criteria that are going to be applied while defining this type of construction. Two approaches are well-known; on the one hand, the classical approach has been to adopt a functional definition based on universal conceptual semantic criteria (Croft 2003); on the other hand, Haspelmath (2010) explains that purely conceptualsemantic criteria are not fully adequate for cross-linguistic comparative purposes. Thus, he mentions that the solution to this problem is the use of comparative concepts based on primitive, universal conceptual-semantic, and formal criteria. It is within this spirit that we assume this methodological practice in our study. The main reason is that taking conceptual semantic criteria and formal criteria as a point of departure to explore adverbial clauses restricts our general understanding of the functional domain of this phenomenon. For instance, the speakers of some languages may prefer encoding the functional domain of adverbial clauses by means of asyndetic clauses, that is, without any overt conjunction, others by syndetic clauses, and still others by hypotactic clauses. This is the expected scenario since what all humans share is a set of cognitive mechanisms and communicative goals, as well as a common system of perception and thought; thus, all languages share the duty of fulfilling certain basic communicative functions (Hetterle 2015: 13). However, it is important to bear in mind that they will fulfill such communicative functions by means of different syntactic constructions and formal mechanisms. In what follows, an adverbial clause will be considered a construction encoding a particular adverbial meaning, which either modifies a main clause, or functions as a framework for subsequent discourse. ${ }^{6}$

\section{Adverbial clauses in vHN}

Adverbial clauses in VHN encode a variety of semantic relations, among them, temporal, conditional, concessive-conditional, cause/reason, concessive, purpose, result, and spatial relations. In what follows, we analyze different types of some of these semantic relations, as well as the formal devices that encode them in vHN. For the sake of space, we restrict our attention to: (i) temporal precedence, (ii) temporal subsequence, (iii) temporal simultaneity, (iv) cause/reason, (v) purpose, (vi) result, and (vii) spatial clauses.

\subsection{Temporal precedence}

Precedence holds for a situation that occur prior to that of the main clause (Hetterle 2015: 48). In (5) the temporal relation encoded in the adverbial clause indicates that by the time the woman had finished sweeping her house, there was another event that had already occurred. In the main clause, on the other hand, the event which happened before the woman finished sweeping her house, is encoded; that is, the act of her getting sick. In this example, the ongoing process, that of the subject being in the state of not yet having

${ }^{6}$ Bickel (1993: 24-36) refers to the modifying function as peripheral subordination and the framework function as adsentential subordination. 
finished the sweeping, is marked by the temporal conjunction achtoui 'before' and by means of the imperfective marker -yaya, suffixed to both the verbal root tlami 'to finish' and the verbal root tlachpa 'to sweep' and ayokana 'not yet'. Moreover, the completion of the event expressed within the main clause is marked by the perfective marker $-k i$, suffixed to the verbal root koko 'to get sick'.

(5) [kemah sihua-tl ayokana tlami-yaya i-chan],

when woman-ABS not.yet finish-IPFV 3sG.POss-house

'When the woman finished sweeping her house,

mo-koko-ki.

REFL-get.sick-PFV

she had gotten sick.'

In the example in (5) ayokana 'not yet' is a negation device that indicates that the event has not been accomplished. This seems to be also attested in other languages, as can be observed in (6) from Eudeve, in (7) from Buru, and in (8) from Lezgian. Veselinova (2015) explains that 'not yet' expressions typically indicate the non-occurrence of an expected action or state but also an anticipation about its imminent realization. She explains that in her sample of 100 unrelated languages, 'not yet' expressions occur in most areas of the world, but are absent in Europe in the form of single, bound or semi-bound, grammaticalized negative temporal markers.

Eudeve (Uto-Aztecan/Cahita; Pennington 1981:77)

(6) [nap cá-que has-do],

2SG.SBJ not.yet come-sUB

'Before you came,

nee vínu ivide-eni-tud.
1sG.SBJ already here-be-IPFV
I was already here.'

Buru (Austronesian/Central Malayo-Polynesian; Grimes 1991: 421)

(7) [da mata mohede],

3sG.SBJ die not.yet

'Before he died,

da stori gam naa.

3sG.SBJ speak like this

this is what he said.'

Lezgian (Nakh-Daghestanian/Lezgic; Haspelmath 1993: 385)

(8) [hele mes.e-laj ōară t-awu-nmaz],

still bed-SREL get.up NEG-do-POSTR

'Before I got up, 


\begin{tabular}{lllll}
\hline$z i$ & rik'e-l & $q^{\prime} a q^{\prime}$ 'an & dağ-lar & xta-na-j. \\
1:GEN heart-SRESS high & mountain-PL & return-AOR-PST \\
'I remembered the tall mountains.' &
\end{tabular}

\subsection{Temporal subsequence}

Subsequence holds for a temporal semantic relation in which 'After $\mathrm{x}$ has happened, then Y' occurs. There seem to be two possible instances of subsequent events. First, those which express a logical relation of chronological succession (e.g. after I woke, I brushed my teeth), and second those which express not only chronological subsequence, but also a semantic relation of cause/reason (e.g. after I felt sick, I went to the hospital).

VHN encodes both types of subsequent events by means of three formal mechanisms: a temporal conjunction kemah 'when', the aspectual suffix - $k i$, and the adverb $y a$ 'already'.

The example in (9) expresses a semantic relation of chronological succession. This temporal arrangement is encoded by means of the perfective marker $-k i$ suffixed to the verbal root mach 'to study' within the clause preceded by the temporal conjunction kemah 'when'; the perfective marker - $k i$ suffixed to the verbal root chihua 'to do' in the main clause also contributes to emphasize that both events already occurred.

(9) [kemah okichpil mo-mach-ti-ki], when boy REFL-study-CAUS-PFV

'When the boy had studied,

$$
\begin{array}{ll}
\text { ki-chihua-ki } \quad \text { teki-tl. } & \\
\text { 3sG.OBJ-do-PFV } & \text { work-ABS } \\
\text { he did his homework.' }
\end{array}
$$

The example in (10) illustrates a semantic relation of cause/reason. The fact that the woman walked all day long triggered the second event; namely the act of her getting tired. Once again, the formal devices which encode the semantic relation are the temporal conjunction kemah 'when', the phrasal adverb ya 'already' and the perfective marker $-k i$ suffixed to the verbal root nehnen 'to walk'. The three elements collaborate to encode the completion of the first event, which in turn motivates the development of the event encoded in the adjacent main clause, by the perfective marker $-k$ suffixed to the verbal root siah 'to get tired'.

\section{(10) [kemah toahui ya neh-nen-ki semilhui-tl],} when woman already RDP-walk-PFV all.day-ABS 'When the woman walked all day long,

siah- $\boldsymbol{k}$.

get.tired-PFV

she got tired.' 
We have shown that subsequent events, such as those provided in (9) and cause/ reason as in (10), are characterized by having a temporal conjunction kemah 'when', a perfective suffix $k i$, and a phrasal adverb ya 'already'. Cross-linguistically, this type of events also tends to be encoded by the same formal devices. Examples (11) and (12) support this analysis. Hetterle (2015: 76-77) explains that cross-linguistically, subsequent events are highly systematic in having past, aoristic, perfective or completive marking in the adverbial clause since after-clauses are past-oriented in that the proposition that they convey precedes the proposition of the main clause, and it is completed at the onset of the main clause event. Observe that both the examples in (11) from Cavineña and (12) from Upper Necaxa Totonac illustrate the use of perfective markers to encode subsequent events.

Cavineña (Tacanan; Guillaume 2008: 124)
(11) [rekwana $=k e j a$ ju-neni-wa $=k e \quad t a a]$, this_stuff_here=LOC.GNL be-random-PFV=LIG EMPH
'After having been around these places,
1SG.GEN mommy die-PFV
my mother died.'
ekwe mamita maju-wa.

Upper Necaxa Totonac (Totonacan; Beck, 2004: 102)

(12) ik-te:ak-tfinta.ma:-pí:-l

1sG.SBJ-path-head-kick-CAUS-extend-PFV

'I stepped on the money and flattened it

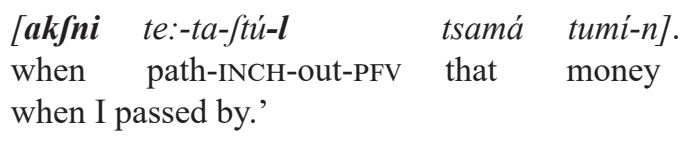

On the other hand, there are languages in which the phrasal adverb 'already' is the only formal mechanism that sheds light on the subsequent event, as indicated in the example in (13) from Tetun. This device is referred to as iamitives. Olsson (2013: 39) shows that in several Southeast Asian languages iamitives appear as markers of sequentiality, as can be seen in the Thai example in (14).

Tetun (Austronesian/Central Malayo-Polynesian; Klinken 1999: 236)

(13) $\left[\right.$ kawen $\left.\boldsymbol{t i}^{\prime} \boldsymbol{a}\right]$,

marry already

'After (we) are married,

tur iha ne'e dei.

sit LOC this only

(we) must live here.' 
Thai (Tai-Kadai/Kam-Tai; Iwasaki and Ingkaphirim 2005: 277; cf. Olsson 2013: 39)

(14) [prachum sèt lécw], meeting finish already '(After) the meeting is over,

khôy pay súu khôsy dii máy softly go buy Thing good Q shall we go shopping?'

\subsection{Simultaneity}

Simultaneity holds for a temporal semantic relation in which two actions or events are, fully or partially, happening at the same time. The example in (15) expresses two simultaneous events. In this construction the event denoted in the kemah 'when' clause, tlankeyah tlakuahyah 'they were still eating', occurs within the same time frame as the event named in the adjacent main clause; that is, okichpil kikuahya sopelik 'the boy was eating candy'. Both events, tlanke 'to finish' and kuah 'to eat', are ongoing processes encoded by the imperfective marker $-y a$.

(15) [kemah tlanke-ya-h tla-kuah-ya-h], when finish-IPFV-PL UNSPEC.OBJ-eat-IPFV-PL

'When they were still eating,

$\begin{array}{lll}\text { okichpil ki-kuah-ya } & \text { sopelik. } \\ \text { Boy } & \text { 3sG.OBJ-eat-IPFV } & \text { candy } \\ \text { the boy was eating a candy.' } & \end{array}$

Thompson and Longacre (1985: 188-189) mention that, cross-linguistically, specific TAM markers, such as the imperfective, continuative, durative, habitual, iterative or progressive aspect, can all encode simultaneous events. Consider the following examples from Tokelau and Wolof, which also show an imperfective aspect marker:

Tokelau (Austronesian/Oceanic; Murik-Vonen 1994: 374)

(16) $\boldsymbol{e}$ puha ki luga ta ahu o te atu

IPFV rise PREP up ART smoke PREP ART skipjack

'The smoke from the skipjack rises up

[kafai $\boldsymbol{e}$ tunu].

When IPFV cook

when it is cooked.' 
Wolof (Niger-Congo/Northern Atlantic; Robert 2010: 481)

(17) maa ngiy génn
PRES.1SG IPFV exit
'I am going out
[yow yaa $\quad$ ngiy dugg].
2SG.SBJ PRES.2SG IPFV enter
(whereas) you, you are coming in.'

\subsection{Cause/reason clauses}

Givón (2001: 335) observes that there is usually no morphosyntactic distinction between cause and reason clauses in the languages of the world. That is, languages usually have the same formal mechanisms to encode these semantic relations. Cause/ reason clauses in VHN are one exception to this cross-linguistic tendency in that these two semantic relations show different morphosyntactic encoding. We will discuss evidence from that in 4.4.1 and 4.4.2.

\subsubsection{Causal clauses}

Givón (2001: 336) explains that prototypical causal clauses involve an external motivation. That is, an external factor that leads the agent to act or cause a state to be possible. Causal clauses in VHN are characterized by the following properties: (i) the clauseinitial adverbial conjunctions pampa 'because', and yekah 'consequently', (ii) the phrasal adverb ya 'already', and (iii) the perfective marker - $k i$. The conjunction pampa 'because' encodes the circumstance (an external motivation) which led to the realization of another event. On the other hand, the result (the resulting state) is asserted in the main clause where the conjunction yekah 'consequently' appears in clause- initial position. Two fine-grained semantic nuances can be also observed: the construction in (18) is an instance in which an agentive external cause occurs, while in (19) the external cause is non-agentive:

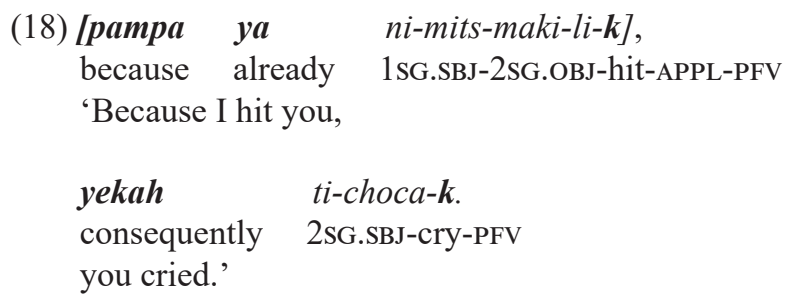

Observe that in (18) the agentive external cause nimitsmakilik 'I hit you' is preceded by the conjunction pampa 'because' and the adverb ya 'already', which work together to make the event denoted by this clause a prominent context. The verbal complex word, nimitsmakilik 'I hit you' has a perfective marker $-k$, to anchor the fact that this event already occurred. Moreover, the resulting event (state to become realized) tichocak 'you 
cried' is encoded by the conjunction yekah 'consequently' and the verb is also marked with the perfective marker $-k$ suffixed to the verb root choca 'to cry'.

In a similar fashion, the causal construction in (19) has the same formal devices. In the example, the clause having the conjunction pampa 'because' in the initial position encodes the context, which led to the realization of another event. In (19), the external cause is non-agentive, tlauitl kuali tlauel 'the rain was heavy', while the clause preceded by the conjunction yekah 'consequently' encodes the result (state to become realized), kipolok chiapopojtli 'it destroyed the street', where the verb root polo 'to destroy' is also marked with the perfective suffix $-k$.

[pampa ya tlaui-tl kuali tlauel],
$\begin{aligned} & \text { because already rain-ABS good } \\ & \text { extremely }\end{aligned}$
$\begin{aligned} & \text { 'Because the rain was heavy, } \\ & \text { consequently 3SG.OBJ-destroy-PFV } \\ & \text { it destroyed the street.' }\end{aligned}$

\subsubsection{Reason clauses}

Givón (2001: 336) mentions that reason clauses involve internal motivations, i.e. either a speaker or a human referent has specific reasons for acting, speaking or thinking in a particular way. However, in VHN, reason clauses may involved an external or an internal reason.

Reason clauses in VHN show three of the properties that were previously illustrated in the preceding type of clauses: (i) the clause-initial adverbial conjunction pampa 'because' (ii) the phrasal adverb ya 'already', and (ii) the perfective marker -ki. However, the examples in (20) and (21) show that reason clauses appear with the adverbial particle san 'just'; a device that does not occur in causal constructions.

Like the fine-grained semantic distinction agentive vs. non-agentive cause illustrated in examples (18) and (19), reason clauses VNH can provide a four-way semantic distinction: an eventive external reason, a non-eventive external reason, an eventive internal reason, and a non-eventive internal reason. We will illustrate examples referring to these semantic distinctions in the following subsections.

\subsubsection{Eventive external reason for the action}

In (20) the clause-initial conjunction pampa 'because' encodes the eventive external reason. By the eventive external reason, we refer to san asiki ichan 'he arrived at his home'. The clause fulfills the encoding of the external reason by means of the conjunction, the phrasal adverb san 'just' which emphasizes that the action has happened, and the perfective marker -ki. Moreover, the main clause encodes the resulting action ya niyohuiki 'I immediately left' by means of the phrasal adverb $y a$ 'already' and the perfective marker $-k i$ on the verbal root yohui 'to go'. 
(20) [pampa san asi-ki i-chan],

because just arrive-PFV 3sG.POss-house

'Because he arrived at his home,

ya ni-yohui-ki.

already 1sG.SBJ-go-PFV

I immediately left.'

\subsubsection{Non-eventive external reason for the action}

In (21) the main clause encodes the result ya niyohuiki 'I left' whose realization was motivated by the non-eventive external reason for the action expressed in the pampa 'because' clause.

(21) [pampa san tlauel tlaseseya-k], because just extremely cold-PFv

'Because it was very cold,

ya ni-yohui-ki.

already 1sG.SBJ-go-PFV

I immediately left.'

\subsubsection{Eventive internal reason for the action}

As can be observed in (22), in the pampa 'because' clause, the phrasal adverb san 'just' encodes the completion of the first event which in turn motivates the development of the situation encoded in the adjacent main clause by the phrasal adverb $y a$ 'already' and the perfective marker $-k$ suffixed to the verbal root tlalo 'to run'.

(22) $n a$

$$
\text { ayok ni-hueli-k ya ni-tlalo-k }
$$

1SG.SBJ not.anymore 1SG.SBJ-be.able-PFV already 1SG.SBJ-run-PFV

'I was not able to run

[pampa san na huehue-tsi].

because just 1SG.SBJ old-DIM

because I am just too old.'

\subsubsection{Non-eventive internal reason for the action}

In (23) the main clause encodes the result ayok ya tlachihki 'he did not do it more' by the phrasal adverb ya 'already' and the perfective marker $-k i$ suffixed to the verbal root chih 'to do'. The realization of this event was motivated by the non-eventive internal reason for the action expressed in the pampa 'because' clause. 


\title{
(23) ayok $\quad \boldsymbol{y a} \quad$ tla-chih-ki \\ not.anymore already UNSPEC.OBJ.-do-PFV \\ 'He did not do it anymore
}

\author{
[pampa san tlahtlako-li]. \\ because just sin-ABS \\ because that is a sin.'
}

As was illustrated above, cause/reason clauses in vHN are characterized by perfective markers. Hetterle (2015: 75) explains that cause/reason clauses in the world's languages tend to be encoded by past tense and perfective aspect marking for the reason that cause/ reason precedes the consequence in the logical order of events, and they are typically realized (completed) at the onset of the consequence.

\subsection{Purpose clauses}

Purpose clauses signal the purpose of the agent for acting as he does in the event encoded by the main clause. Thus, the main clause is typically active/agentive (Givón, 2001: 337). Purpose clauses in VHN show the following morphosyntactic properties: (i) The clause-initial adverbial conjunctions para 'so as' and para ma 'so that', (ii) the purpose marker-ti, and (iii) the future morpheme $-s$.

Purpose clauses have the formal devices mentioned above since they express an event, which must be unrealized at the time of the event encoded in the main clause. Thompson and Longacre (1985: 187) explain that same-subject and different-subject purpose clauses are encoded by different properties in the world's languages. Purpose clauses in VHN behave in the same way, as explained below.

\subsubsection{Same-subject purpose clauses}

Same-subject purpose clauses are encoded by the future morpheme $-s$, the purpose marker - $t i$, and the adverbial conjunction para 'so as'. However, the distribution of these formal devices depends on whether the same-subject purpose clause is either positive or negative.

On the one hand, when the same-subject purpose clause is positive, it has the future morpheme $-s$ and the purpose marker $-t i .^{7}$ For example, in (24) the main clause is expressed, by the future morpheme $-s$ suffixed to the verbal root teki 'to work', the means by which the agent intends to realize the purpose encoded in the purpose clause. In other words, in this construction the main participant (Juan) will work in the milpa in order to obtain the realization of a particular event (to get a lot of money).

${ }^{7}$ There is a casual homophony of the causative suffix $-t i$, and the polysemous use of - $t i$ when it functions as a purpose marker in (24), as well as a directional suffix in (34). 


(24) Juan teki-ti-s milan
Juan work-CAUS-FUT field
'Juan will (go to) work in the milpa
[ki-pia-ti miyac tomin].
3sG.OBJ-have-PURP a.lot.of money
in order to have a lot of money.'

On the other hand, when the same-subject purpose clause is negative, it is encoded by the future morpheme $-s$, the negative marker $a m o$, and the clause-initial adverbial conjunction para 'so as'. For example, in (25) the para 'so as' purpose clause encodes the the main clause agent's action by means of the negative marker amo and the purpose marker $-t i$.

(25) amo yoyon-paka-s

NEG clothes-wash-FUT

'She will not wash her clothes

$\begin{array}{lll}\text { [para amo ki-mah-kahua-ti } & \text { atl]. } \\ \text { so.as NEG 3sG.OBJ-hand-throw-PURP } & \text { water } \\ \text { so as not to waste water.' } & \end{array}$

\subsubsection{Different-subject purpose clauses}

Different-subject purpose clauses are marked by the future morpheme $-s$, the purpose marker - $t i$, and the adverbial conjunction para $m a$ 'so that'. However, these constructions show specific encoding devices depending on whether the different-subject purpose clause is either positive or negative.

In (26) the different-subject purpose clause is positive. In this construction, the purpose clause para ma tlahuikati 'so that she (the girl) will take it home' is the purpose for what the main clause agent did in the main clause, namely, tlatlanehs ne sihuapil 'he gave it to the girl'.

$\begin{array}{lll}\text { (27) } \text { tla-tlaneh-s } & \text { ne } & \text { sihuapil } \\ \text { UNSPEC.OBJ-share-FUT } & \text { DET } & \text { girl }\end{array}$

'He will give it to the girl

[para ma tla-huika-ti].

so that UNSPEC.OBJ-take-PURP

so that she (the girl) will take it home.'

In (28) the different-subject purpose clause is negative. In this example the situation encoded in the main clause na nikchihuas 'I will do it' is performed with the intention of bringing about the situation denoted by the purpose clause; that is, para ma amo sihuapil siahui 'so that the girl does not get tired'. 
(28) na ni-tla-chihua-s

1SG.SBJ 1SG.SBJ-UNSPEC.OBJ-do-FUT

'I will do it

$\begin{array}{lllll}\text { [para } & \text { ma } & \text { amo } & \text { sihuapil } & \text { siahui]. } \\ \text { so } & \text { that } & \text { NEG } & \text { girl } & \text { get.tired }\end{array}$

so that the girl does not get tired.'

Note that both same-subject and different-subject purpose clauses in VHN are deprived of TAM markers. This aspect is in line with Schmidtke-Bode's proposal (2009: 43) in which purpose clauses have no time reference in relation to the main clause. The reason is that there is no strict communicative need to specify the temporal location of the purposive situation. In this respect, Givón (1990) mentions that the more predictable a clausal feature is $v i s-\grave{a}$-vis its immediate inter-clausal context, the more likely it is to be left unmarked or to be encoded as less finite.

\subsection{Result clauses}

Result clauses describe a consequence or conclusion derived from the main clause (Diessel 2001). Dixon (2009) explains that in this type of construction, the dependent clause encodes a natural consequence of what is described by the main clause (leadup). Thus, result clauses in VHN show the following morphosyntactic properties: (i) the clause-initial adverbial conjunctions huankino 'then' and yeka 'consequently' and (ii) the perfective marker $-k i$.

Result clauses are systematically associated with the above formal properties since the main clause encodes what leads to the realization of another event (lead-up) by means of the perfective marker $-k i$ and the adverbial clause encodes a natural consequence of what is described by the main clause by means of the perfective marker -ki. We provide in what follows a preliminary empirical sketch of the behavior of huankino 'then' clauses and yeka 'consequently' clauses.

\subsubsection{Huankino 'then' clauses}

In the example in (29), the event toahui nehnenk semilhuitl 'the woman walked all day long' is encoded in the main clause (lead-up) by means of the perfective marker - $k(i)$ suffixed to the verbal root nehnen 'to walk'. Moreover, the fact that the woman got tired is supported by the conjunction huankino 'then' as well by means of the perfective - $k(i)$ suffixed to the verbal root siah 'to get tired'. This event is the natural consequence of the first event.

(29) toahui neh-nen-k semilhui-tl, woman RDP-walk-PFV all.day.long-ABS

'The woman walked all day long, 
[huankino siah-k].

then get.tired-PFV

then, she got tired.'

In a similar fashion, the example in (30) encodes a result clause. In this construction, the event denoted within the main clause (lead-up), Juan mokokoaki 'Juan got sick', is marked by the perfective marker $-k i$ suffixed to the verbal root kokoa 'to get sick'. In a similar way as in (29), the conjunction huankino 'then' within the adverbial clause encodes the natural consequence; that is, iaki kokoxkali 'he went to the hospital', where the verb ia 'to go' shows the perfective marker $-k i$.

(30) Juan mo-kokoa-ki,

Juan MED-make.sick-PFV ${ }^{8}$

'Juan got sick,

[huankino ia-ki kokoh-kali].

then go-PFV pain-house

then, he went to the hospital.'

\subsubsection{Yeka 'consequently' clauses}

In the example in (31) the yeka 'consequently' clause conveys the expected situation Note that the verb in the consequence clause is encoded by means of the perfective marker $-k(i)$.

$\begin{array}{lll}\text { okichpil ki-kuah-k} & \text { sopelik, } \\ \text { boy } & \text { 3sG.OBJ-eat-PFV } & \text { candy } \\ \text { 'The boy ate candy, } & \end{array}$

$\begin{array}{lll}\text { [yeka } & \text { semilhui-tl } & \text { mo-tlalo-k]. } \\ \text { consequently } & \text { all.day.long-ABS } & \text { REFL-run-PFV } \\ \text { consequently, he ran all day long.' } & \end{array}$

The same encoding devices are also observed in the example in (32). In this construction the event encoded in the main clause, okichpil momachtiki 'the boy was made to study', shows a perfective suffix -ki. Moreover, the fact that the boy did not do his work is encoded in yeka 'consequently' clause by means of the perfective -ki suffixed to the verbal root chihua 'to do'. This event is the natural consequence of the first event.

(32) okichpil mo-mach-ti-ki, boy REFL-study-CAUS-PFV

'The boy was made to study,

${ }^{8}$ The suffix mo- functioning as a middle is probably influenced by the middle voice from Spanish (cf. Peregrina 2018). 


$\begin{array}{llll}\text { [yeka amo } & \text { ki-chihua-ki } & \text { teki-tl]. } \\ \text { consequently NEG } & \text { 3SG.OBJ-do-PFV } & \text { work-ABS } \\ \text { since he hadn't done his homework.' } & \end{array}$

\subsection{Spatial clauses}

Spatial clauses are those constructions, which describe the place and/or direction where the event mentioned in the main clause takes place. This interclausal semantic relation shows the following morphosyntactic properties: (i) The adverbial conjunction kampa 'where' and (ii) the directional markers -to and -ti.

Spatial clauses occur in VHN with the above formal devices due to the fact that they underscore the directional goal of motion; that is, they specify the direction in which the action described by the verb in the main clause takes place. In what follows, we discuss some examples.

In (33) the main clause encodes the movement of a person with respect to a given frame of reference. On the other hand, the kampa 'where' clause encodes the location towards which the action described by the verb in the main clause takes place by means of the directional marker - $t i$ suffixed to the verbal root kasi 'to find'.

$\begin{array}{ll}\text { (33) ya } & i a-k i \\ \text { 3SG.SBJ } & \text { go-PFV } \\ \text { 'He went } & \\ & \\ \text { [kampa } & \text { kasi-ti]. } \\ \text { where } & \text { find-DIR } \\ \text { where she saw him.' }\end{array}$

In (34), the kampa 'where' clause indicates the directional goal of motion by means of the directional marker - $t i$ suffixed to the verbal root teki 'to work' since it specifies the direction in which the action described by the verb in the main clause takes place.

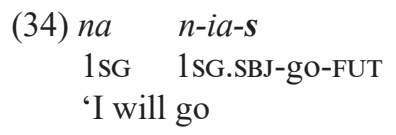

[kampa ni-teki-ti-ti] where 1sG.SBJ-work-CAUS-DIR where I will work.'

Cross-linguistically spatial clauses may appear with a subordinator or an adverbial conjunction and a locative or directional marker at the same time. However, according to Nefedov (2015: 209), in such instances, the subordinator or adverbial conjunction is redundant, since the spatial adverbial clause is already marked with either a locative or directional, which sheds light on the type of semantic relation. Thus, the adverbial 
conjunction kampa 'where' is redundant since the directional marker -ti already encodes the directional goal of motion.

Spatial clauses in VHN show a number of remarkable and puzzling properties whose analysis affords us new insights on the cross-linguistic behavior of this complex construction. Main clauses in spatial constructions tend to lack locative and directional markers since these notions are already implied within the verb of motion, whose meaning indicates a movement or change in position. On the other hand, spatial clauses allow the occurrence of directional markers, which indicate location or direction where the action described by the verb in the main clause takes place. This is illustrated in examples (33) and (34).

However, if the verb encoded within the main clause is not a verb of movement, the semantic relation of space is specified by a directional element suffixed to the main verb. In example (35), the main clause verb, kohua 'to buy', does not denote a motion event. However, the directional marker -to, which is suffixed to the verbal root, indicates a direction towards the agent entity that will go to buy. Thus, the adverbial clause is preceded by the conjunction kampa 'where' which encodes the place where the action described by the verb in the main clause takes place. Note that this adverbial clause lacks other locative or directional marker; in its place the verb is marked with a future suffix $-s$, indicating that the event will occur somehow in a following space of time-frame.

\section{(35) tla-kohua-to}

UNSPEC.OBJ-buy-DIR

'He will (go to) buy it

[kampa asi-s].
where arrive-FUT
where he arrives.'

\section{Final remarks}

This paper has brought to light the range of formal mechanisms that vHN use to signal adverbial relations. We have shown that different semantic relations take on specific formal mechanisms to express particular communicative situations. For instance, temporal precedence shows the phrasal adverb ayokana 'not yet' since this semantic relation expresses the non-realization of a situation that may come to hold in the future. The semantic relation of subsequence shows the perfective marker $-k i$ since it helps to encode the sequential order in which the events happen; that is, the development of events in a chronological succession. Spatial clauses are systematically associated with the directional markers -to and - $t i$, since these markers specify the direction in which the action described by the verb in the main clause takes place.

In our analysis, we have discussed the functional, semantic and communicative motivations in the encoding of adverbial constructions. We also refer to the particular devices that VHN adopts to encode such semantic relations. We argue that such properties are not arbitrary. Cross-linguistic studies of this functional domain also have shown the use of similar devices for the same semantic relations. Thus, the semantic and communicative 
semantic relations and the particular properties that have discussed for adverbial clauses are clearly valid cross-linguistically. This has led us to conclude that the behavior of these constructions in VHN aligns with respect to certain functional cross-linguistic tendencies.

\section{References}

Andrews, J. Richard (1975). Introduction to Classical Nahuatl. Austin \& London: University of Texas Press.

Beck, David (2004). A grammatical sketch of Upper Necaxa Totonac. München: LINcom: Europa.

Bickel, Balthasar (1993). Belhare subordination and the theory of topic. In Karen H. Ebert (ed.). Studies in clause linkage, pp. 23-55. Zürich: ASAS.

Campbell, Lyle (1997). American Indian languages: The historical linguistics of Native America. Oxford: Oxford University Press.

Canger, Una (1997). Arte de Horacio Carochi. In Klaus Zimmermann (ed.). La descripción de las lenguas amerindias en la época colonial, pp. 59-74. Madrid: Verbuert Iberoamericana.

Carochi, Horacio (1645). Arte de la lengva Mexicana con la declaración de los adverbios della. México: Iuan Ruyz.

Comrie, Bernard (1981). Language universals and linguistic typology: Syntax and morphology. Chicago: University Press.

Cristofaro, Sonia (2003). Subordination. Oxford: Oxford University Press.

Croft, William (2003). Typology and universals. 2nd edn. Cambridge: Cambridge University Press.

Dakin, Karen (2004). Prólogo. In Zarina Estrada-Fernández; Crescencio Buitimea Valenzuela; Adriana Elizabeth Gurrola Camacho; María Elena Castillo Celaya; Anabela Carlón Flores (eds.). Diccionario yaqui-español y textos. Obra de preservación lingüistica, pp. 13-20. México: Editorial Plaza y Valdés/Universidad de Sonora.

Diessel, Holger (2001). The ordering distribution of main and adverbial clauses: A typological study. Language 77(2): 433-455. doi: 10.1353/lan.2001.0152

Dixon, R. M. W. (2009). The semantics of clause linking in typological perspective. In R. M. W. Dixon; Alexandra Aikhenvald (eds.). The semantics of clause linking: A cross-linguistic typology, pp. 1-55. Oxford: Oxford University Press.

Givón, T. (1990). Syntax: A functional-typological introduction, volume II. Amsterdam: John Benjamins.

Givón, T. (2001). Syntax: An introduction, volume II. Amsterdam: John Benjamins.

Grimes, Charles (1991). The Buru language of Eastern Indonesia (Ph. D. dissertation in Linguistics). Canberra: Australian National University.

Guillaume, Antoine (2008). A grammar of Cavineña. Berlin: Mouton de Gruyter. 


\section{OLGUÍN-MARTÍNEZ \& ESTRADA-FERNÁNDEZ - ADVERBIAL CLAUSES...}

Haspelmath, Martin (1993). A grammar of Lezgian. Berlin: Mouton de Gruyter.

Haspelmath, Martin (2010). Comparative concepts and descriptive categories in cross-linguistic studies. Language 86(3): 663-687. doi: 10.1353/lan.2010.0021

Hetterle, Katja (2015). Adverbial clauses in cross-linguistic perspective. Berlin: Mouton de Gruyter.

Iwasaki, Shoichi; Preeya Ingkaphirom (2005). A reference grammar of Thai. Cambridge: Cambridge University Press.

Klinken, Catharina (1999). A grammar of the Fehan dialect of Tetun, an Austronesian language of West Timor (Ph. D. dissertation in Linguistics). Canberra: Australian National University.

Link at: http://hdl.handle.net/1885/145393 doi: $\underline{10.25911 / 5 \mathrm{~d} 67 \mathrm{~b} 128 \mathrm{c} 7 \mathrm{e} 1 \mathrm{~d}}$

Kortmann, Bernd (1997). Adverbial subordination. A typology and history of adverbial subordinators based on European languages. Berlin: Mouton de Gruyter.

Launey, Michel (2011). An introduction to Classical Nahuatl. Cambridge: Cambridge University Press.

Muruvik-Vonen, Arnfinn (1994). The expression of temporal and aspectual relations in Tokelau narratives. In Carl Bache; Hans Basboll; Carl-Erik Lindberg (eds.). Tense, aspect and action: Empirical and theoretical contributions to language typology, pp. 371-396. Berlin: Mouton de Gruyter.

Nefedov, Andrey (2015). Clause linkage in Ket. LOT Dissertation Series.

Link at: https://www.lotpublications.nl/Documents/408 fulltext.pdf

Olsson, Bruno (2013). Iamitives: Perfects in Southeast Asia and beyond (MA thesis in Linguistics). Stockholm: Stockholm University.

Link at: http://www.diva-portal.org/smash/record.jsf?pid=diva2\%3A633203\&dswid=-8331

Pennington, Campbell (1981). Arte y vocabulario de la lengua Dohema, Heve o Eudeva. México: UNAM.

Peregrina Llanes, Manuel (2015). Cuentos en Náhuatl Huasteca Veracruzana. México: Universidad de Sonora.

Peregrina Llanes, Manuel (2018). Referencia en náhuatl. Un análisis discursivo. Hermosillo: Universidad de Sonora.

Robert, Stéphane (2010). Clause chaining and conjugation in Wolof: A typology of parataxis and its semantics. In Isabelle Bril (ed.). Clause linking and clause hierarchy. Syntax and pragmatics, pp. 469-498. Amsterdam: John Benjamins. https://doi.org/10.1075/slcs.121.15rob

Schmidtke-Bode, Karsten (2009). A typology of purpose clauses. Amsterdam: John Benjamins. https://doi.org/10.1075/tsl.88

Sullivan, Thelma D. (1988). Compendio de la gramática náhuatl. México: Universidad Nacional Autónoma de México.

Thompson, Sandra; Longacre, Robert (1985). Adverbial clauses. In Timothy Shopen (ed.). Language typology and syntactic description, Volume II: Complex constructions, pp. 171-234. Cambridge: Cambridge University Press. 
Thompson, Sandra; Longacre, Robert; Hwang, Shin (2007). Adverbial clauses. In Timothy Shopen, (ed.). Language typology and syntactic description, Volume II: Complex constructions, pp. 237-300. Cambridge: Cambridge University. https://doi.org/10.1017/CBO9780511619434.005

Veselinova, Ljuba (2015). Not-yet-expressions in the languages of the World: Special negative adverbs or a separate gram type? Handout 11th conference of the Association for Linguistic Typology. New Mexico.

Whorf, Benjamin L. (1937). The origin of Aztec TL. American Anthropologist 39(2): 265-274.

Recebido:26/10/2019

Versão revista e corrigida: 13/1/2019

Aceito: 15/1/2020.

LIAMES, Campinas, SP, v. 20, 1-21, e020001, 2020 